\title{
ЛИТОЛОГИЯ
}

УДК 551.24

\section{Дырчатые брекчиевые известняки Уфимского плато и проблема их происхождения}

\section{А.Ю. Кисин}

ИГГ УрО РАН, 620016, Екатеринбург, ул. Академика Вонсовского, 15

E-mail: kissin@igg.uran.ru

(Статья поступила в редакцию 31 мая 2016 г.)

Уфимским плато называют геоморфологическое поднятие, ограничивающее с запада Предуральский краевой прогиб на широте г. Екатеринбурга. На плато и прилегающей части прогиба распространены необычные дырчатые брекчиевые известняки (ДБИ). Брекчии залегают на границе нижне- и верхнекунгурских отложений $\left(\mathrm{P}_{1}\right)$ и считаются осадочными образованиями. Проведенные исследования привели к выводу, что ДБИ образовались в результате массовой дегазации глубинных участков коры, разжижения слабо консолидированных осадочных пород и их сползания в пониженные участки рельефа. Иногда ДБИ обогащены мелкими ксенолитами глубинных пород и минералов, вынесенных в составе эруптивных брекчий. При прохождении газа через пористую среду происходит падение его давления (дросселирование газа), сопровождающееся изменением температуры (эффект Джоуля-Томпсона). Этим объясняется появление иногда стёкол, шлаковых частиц и, возможно, газогидратов.

Ключевые слова: Уфимское плато, глубинная дегазаџия, эруптивные брекчии, газогидраты.

DOI: 10.17072/psu.geol.32.49

\section{Введение}

Дырчатые брекчиевые известняки (ДБИ) всегда привлекали внимание исследователей Уфимского плато своим необычным видом. Подробные описания их даны Н.В. Дорофеевым [3] и В.Д. Наливкиным $[13,14]$ под названием лемезинские ДБИ (по р. Лемеза). Отмечалось, что ДБИ распространены по склонам и у подножья плато. По западному склону мощность их составляет первые метры, на востоке, на границе с Предуральским прогибом, достигает 110 м, а еще восточнее быстро падает до полного выклинивания [14]. По восточной границе прогиба, ЮрюзаноСылвенской депрессии, вновь отмечается увеличение мощности брекчий, хотя из приведенных описаний нет ясности, о каких именно брекчиях идет речь. По представлениям Н.В. Дорофеева и В.Д. Наливкина, ДБИ залегают на размытой поверхности артинских отложений нижней перми. По уточненным данным [15], ДБИ занимают пограничное положение между нижне- и верхнекунгурскими отложениями ранней перми. Состоят они из обломков и галек местных пород (известняков и мергелей), сцементированных карбонатным материалом с высоким содержанием глинистого вещества. Отмечаются единичные находки галек уральского происхождения [3]. Для ДБИ характерна высокая кавернозность. Каверны нередко имеют угловатые очертания и считаются результатом выщелачивания легко раство- 
римого вещества.

По мнению Н.В. Дорофеева [3], образование ДБИ выглядит следующим образом. В конце артинского века плато испытало воздымание и поднялось над уровнем моря. Последовал интенсивный размыв, особенно вдоль восточного крутого склона. В начале кунгурского века территория вновь опустилась и образовался мелководный бассейн. «Из насыщенных солями вод выпадают карбонатные осадки и гипсы, цементирующие всю массу накопившегося рыхлого материала горных шлейфов, осыпей вокруг островов, перемытые и измельченные осадки в заливе, делювий и аллювий» [3, с. 140-141]. После восстановления континентального режима «...водные растворы, циркулируя по сцементированной известковистыми частицами и гипсом породе, уносят легко растворимые вещества цемента и обломков. В результате в разрезе на нижней границе кунгурских отложений мы видим дырчатый брекчиевый известняк во всех его разнообразных видах» [3, с.141], (курсив наш - А.К.). Итак, в условиях суши происходят размыв поверхности и накопление рыхлого материала. Затем в условиях мелководья имеет место цементация рыхлого материала карбонатами и гипсом. И наконец, опять в условиях суши происходит вынос циркулирующими водами легко растворимых соединений (образование кавернозности).

Аналогичную точку зрения высказал В.Д. Наливкин $[13,14]$. «Совместное рассмотрение мощностей, состава и фаций лемазинских брекчиевых известняков отчетливо показывает, что эти известняки являются обычной осадочной породой, отложившейся в водной среде...» [13, с. 89]. Г.А. Мизенс, изучая ДБИ вдоль восточной границы плато от д. Марийские Ключики на севере и до р. Юрюзань на юге, пришел к выводу, что в Предуральском прогибе они имеют дебритную природу [12]. Как видно из краткого и, вероятно, неполного обзора, исследователи единодушны в мнении об осадочном происхождении ДБИ.
Наш интерес к ДБИ вызван поиском пород, генетически связанных с эруптивными брекчиями, которые прогнозировались автором [6] на площади КунгурскоКрасноуфимского свода, слагающего основную часть плато. Необычность вида и многообразие ДБИ в различных обнажениях (рис. 1) привлекли к ним внимание как к возможному продукту эруптивной деятельности на площади свода.

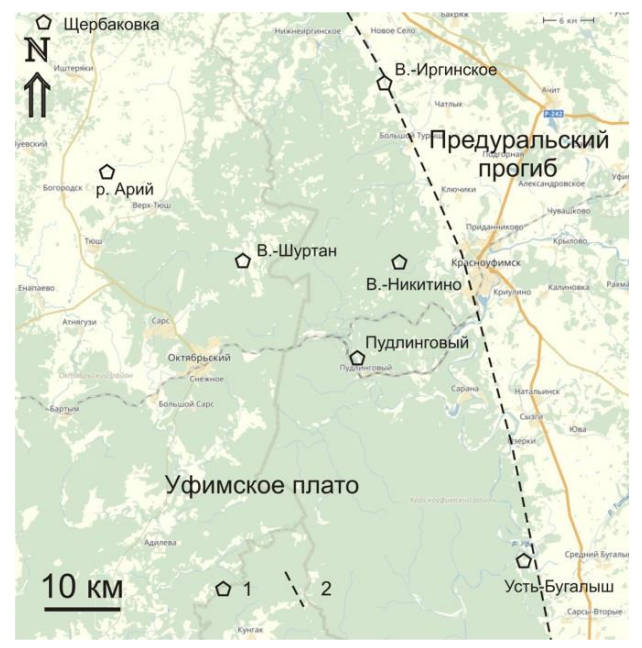

Рис. 1.Места исследованных обнажений ДБИ, описанных в статье: 1 - обнажения ДБИ; 2 гранииа Уфимского плато и Предуральского прогиба

\section{Особенности нахождения ДБИ}

ДБИ - это карбонатные брекчии с карбонатным цементом, с переменным содержанием каверн округлой или угловатой формы. Собственно сами лемазинские ДБИ (с р. Лемеза) слабо кавернозные (рис. 2), по сравнению с ДБИ с Уфимского плато. Предшественники добросовестно описали состав обломков в ДБИ (известняки и мергели), но не отметили среди них обломков самих ДБИ, т. е. более ранних аналогичных образований. Автор наблюдал их в глыбах ДБИ в карьере на правом берегу р. Иргина, около моста на южной окраине д. В. Иргина (рис. 3), в карьере на правом берегу р. Большой Телес около б. д. Щербаковка (рис. 4) и в некоторых других местах. Для осадочных брекчий это выглядит несколько странно. Неоднократное образование ДБИ противоречит 
модели Н.В. Дорофеева, изложенной выше. В желвакоподобных блокахксенолитах ранних ДБИ часто наблюдается укрупнение каверн к иентральной части блока (рис. 3), что нельзя объяснить с позиций вышеупомянутой модели. Около д. В. Шуртан каверны в ДБИ нередко достигают 10-15 см в поперечнике (рис. 5). Около одной такой крупной каверны наблюдается много мелких обломков плитчатых мергелистых известняков (цемент базальный), которые плавно ее огибают (рис. 6). Все ксенолиты «плавающие», несоприкасающиеся между собой, что весьма типично для ДБИ, и ориентировка их в данном случае могла быть вызвана ростом газового пузыря в вязкой грязевой массе. Очень часто наблюдаются каверны внутри ксенолитов плитчатой формы (мергелей или слоистых известняков), прерывающих и частично раздвигающих их. В ДБИ на р. Арий наблюдался ксенолит тонкослоистой карбонатной породы, раскрытый подобно вееру.

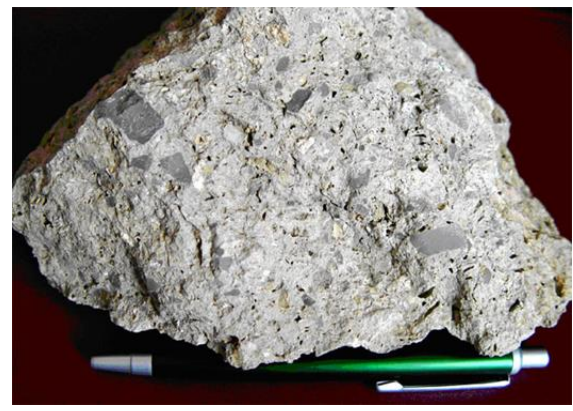

Рис. 2. Вид типичной лемазинской брекчии ( $p$. Лемеза)

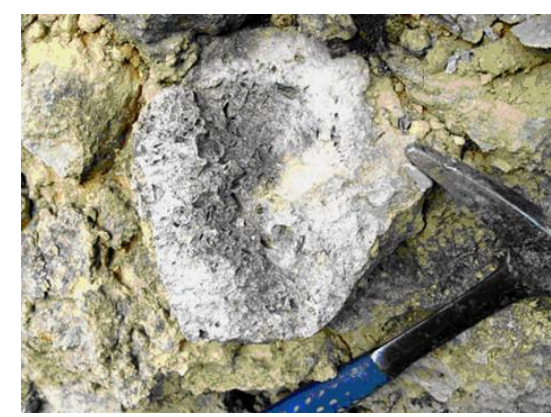

Рис. 3. Угловатый блок-ксенолит в ДБИ около д. В. Иргина; иемент представлен мелкозернистым карбонатом с большим количеством округлых каверн размером до 2 см

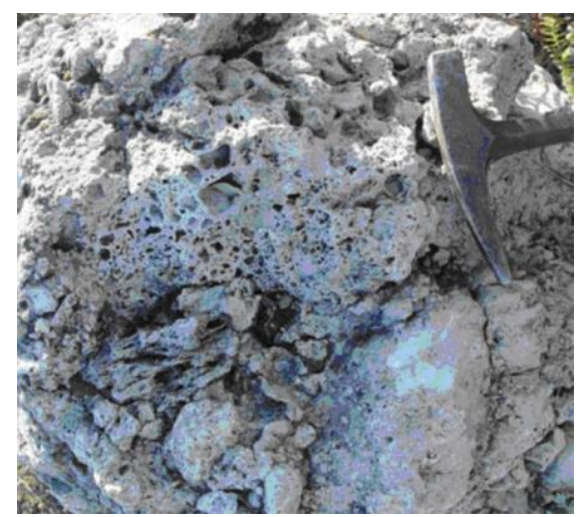

Рис. 4. Обломки ранних ДБИ в обнажении ДБИ в щебеночном карьере около д. Щербаковка (северо-западный склон плато)

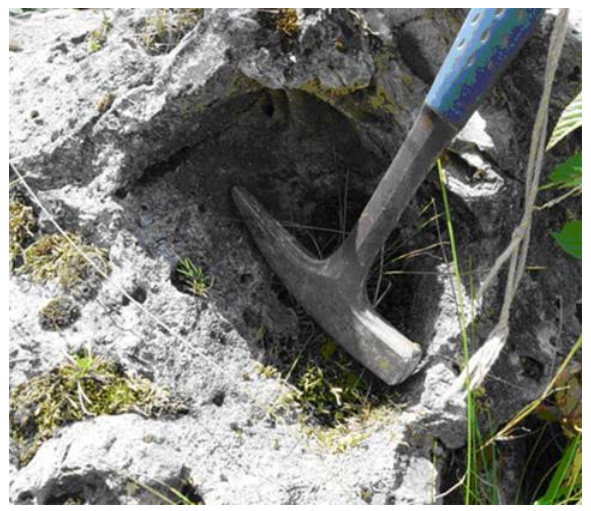

Рис. 5.Крупная каверна в ДБИ около д. Верхний Шуртан (западный склон плато); обратите внимание на округлую форму каверны

Раскрытое пространство заполнено сильно кавернозной карбонатной массой. Внешний край «веера» слегка деформирован. Надо сказать, что есть значительные отличия между типичными лемазинскими ДБИ (р. Лемеза, д. Малоустьикинское, д. Таймеево, д. Бартым, п. Манчаж и др.) Предуральского прогиба и ДБИ восточного и западного подножий плато, его склонов и осевой (апикальной) части. В первом случае преобладает мелкий гравийногалечный (сортированный) материал карбонатных пород, а кавернозность цемента пониженная (рис. 2). Во втором случае преобладает разноразмерный неокатанный материал, а размеры каверн могут достигать 20 см и более (рис. 3-6).

У восточного подножья плато (p. Иргина, д. Марийские Ключики, д. Нижнее Никитино) обломочный материал в ДБИ 
почти неокатанный, несортированный по размеру, а кавернозность породы весьма неравномерная. На склонах плато и в его апикальной части обломочный материал в ДБИ может отсутствовать, а кавернозность может быть очень высокой.

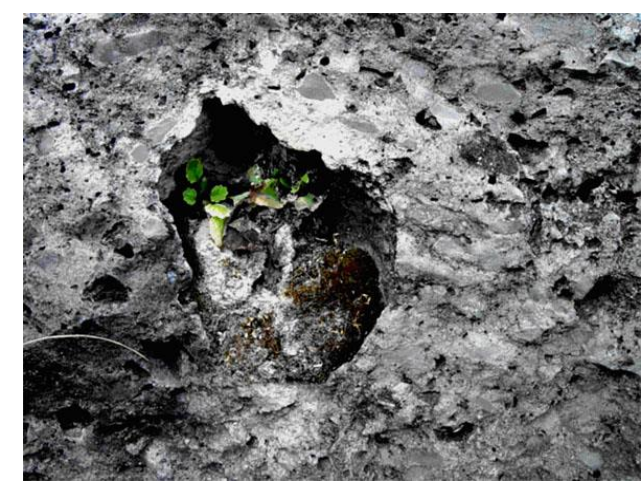

Рис. 6.Характер ориентировки обломков пород (темно-серые) вблизи крупной каверны в ДБИ (окрестности д. Верхний Шуртан)

Около д. Усть-Бугалыш (восточное подножье плато) имеется несколько небольших карьеров на щебень. В одном из них, отрабатываемом в настоящее время, вскрыты ДБИ, залегающие на светлом тонкослоистом мергеле. Падение слоистости на восток под углом $8-10^{0}$. Контакт ДБИ с мергелями резкий, но очень неровный: некоторые блоки вдавлены в мергели на глубину до 0,5 м (рис. 7 и 8). Падение контакта в целом согласное слоистости мергелей. Признаков размыва пород не наблюдается. В интервале около 0,5 м от контакта с ДБИ мергели осветлены и сильно деформированы: пластичные слои

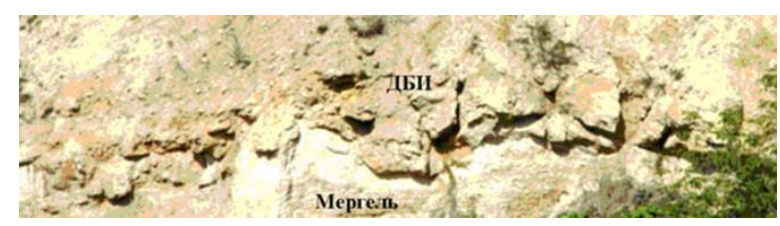

Рис. 7.Плащеобразное залегание ДБИ на мергеле (карьер, д. Усть-Бугальиш)

имеют многочисленные пережимы и раздувы, смяты в складки; хрупкие слои превращены в брекчию. Иногда эта брекчия в виде заливов причудливой формы внедряется в вышележащие ДБИ на глубину до
1,5 м (рис. 9).

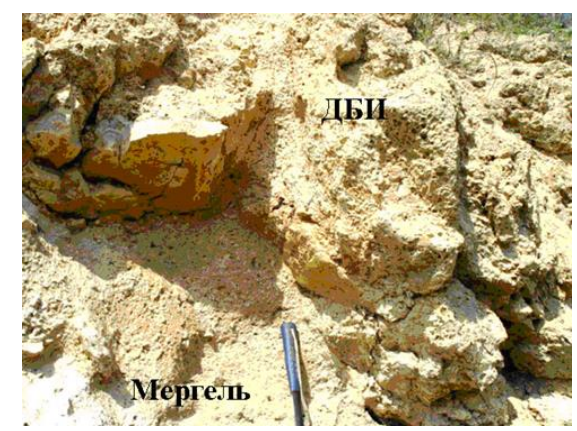

Рис. 8.Контакт ДБИ с подстилающим мергелем (фрагмент рис. 7)

Асимметричное строение валов деформированных мергелей с более крутым восточным склоном свидетельствует о горизонтальном перемещении ДБИ по поверхности мергеля. Но перемещение это было крайне незначительным, поскольку отсутствуют поверхности срыва. Вдавленные в мергели блоки ДБИ показывают, что они ложились на еще неуплотненные известково-глинистые осадки, но сами были уже достаточно прочнылм. Границы блоков внутри толщи ДБИ просматриваются с трудом, поскольку пространство между ними также выполняют кавернозные известковые породы.

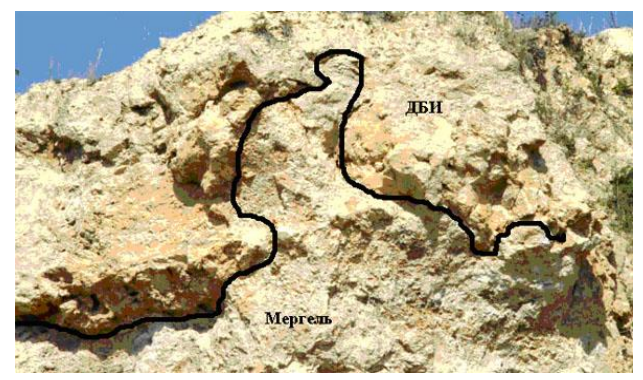

Рис. 9. Внедрение катаклазированного мергеля в вышележашие ДБИ. Высота внедренного тела 1,5 м. Контакт прорисован из-за слабой контрастности изображения (борт карьера, д. Усть-Бугальиш)

Условия залегания ДБИ, наблюдаемые в карьере около д. Усть-Бугалыш, соответствуют признакам грязевых потоков. Несмотря на прекрасную обнаженность ДБИ в данном карьере, многие моменты их образования остаются сложными для 
понимания. Например, при общей комковато-массивной текстуре породы появляются отчетливо тонкослочстые участки с неясными гранищами (рис. 1012).

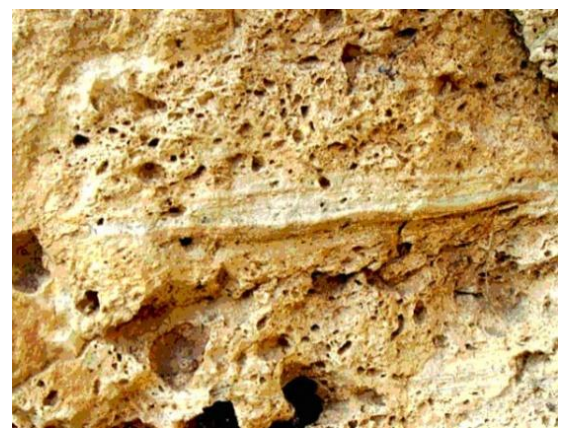

Рис. 10. Особенности внутреннего строения ДБИ: фрагмент слоистой породы без отчетливых грании (борт карьера, д. У.-Бугалыш); ширина изображенного участка 0.3 м

Отнести такие слоистые породы к ксенолитам мешает их ориентировка, согласная снивелированной поверхности контакта ДБИ с мергелями, сильно уплощенная форма и отсутствие ясно выраженных границ. Внешне они больше похожи на реликтовые образования, чем на ксенолиты. На рис. 11 видно, как комковатопузыристая масса ДБИ слагает стенку крупной каверны некарстового происхождения. Распределение и форма каверн указывают, что насыщение газами породы произошло после ее образования, но до её литификации. Аналогичный характер залегания ДБИ на светлых доломитистых мергелях наблюдается в уступе карьера на p. Арий, в 1 км ниже д. Горны, на северозападном склоне плато.

Карьер отрабатывался для сельскохозяйственных нужд и был закрыт около 2000 г. Карьером вскрыт крутой высокий борт долины р. Арий и его крупного правого притока. Высота уступа достигает 12-15 м. Верхняя часть разреза сложена ДБИ мощностью около 3 м. Порода массивная желтовато-бурого цвета и практически не содержит обломков пород, но характеризуется очень высокой кавернозностью.

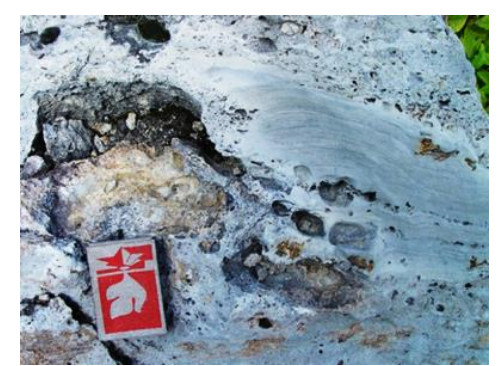

Рис. 11. Фрагмент тонкослоистого мергеля в ДБИ и характер распределения каверн (карьер, д. У.-Бугалыш)

Контакт с подстилающими мергелями неровный и резкий. Мергели в зоне контакта, мощностью около 0,5 м, представлены мучнистой дезинтегрированной массой. Ниже, в интервале 1,0-1,5 м, лежат деформированные мергели, а еще ниже залегание их становится спокойным. Только местами, на удалении до 3 м от контакта с ДБИ, наблюдаются слабые деформации мергелей. Вся толща падает на запад под углом 5-6 ${ }^{0}$.

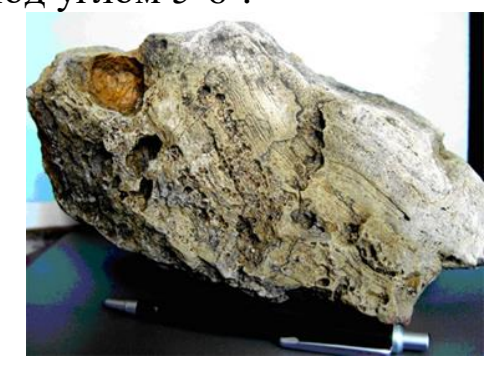

Рис. 12.Тонкослоистый глинистый известняк при поступлении воды и газов резко увеличил пористость и испытал локальные деформации; отчетливо видны изгибы слоев и микросдвиги около крупных газовых пузырей (участок Верхний Бияваи, юго-западный склон плато)

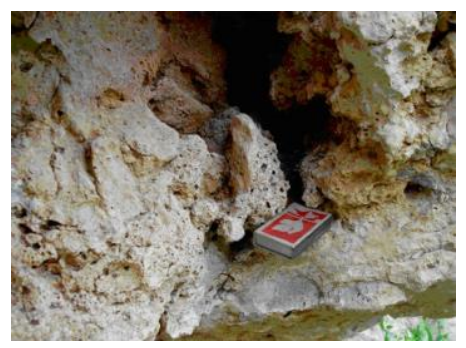

Рис. 13.Крупная каверна в ДБИ, лежащих на мергеле; стенки сложены обломками ДБИ, сцементированными вспененной глинистокарбонатной массой; это показывает, что сама каверна была заполнена водой или газом. Карьер, д. Усть-Бугалыш 
В 0,5 км выше карьера по левому борту правого притока р. Арий есть резко выраженный в рельефе, но очень короткий лог протяженностью не более 100 м. По обоим бортам лога обнажаются ДБИ, богатые обломочным материалом. Еще одно крупное обнажение ДБИ уступом выходит в истоке лога. В основании обнажения наблюдается грот с плоским днищем и куполовидной кровлей (рис. 14).

Ширина ниши 4 м, высота около 1,5 м, днище плоское. В ДБИ просматривается неотчетливая слоистость, также рисующая свод. Следовательно, грот не является карстовым образованием и сформировался одновременно с ДБИ. Внешне он сильно напоминает «газовые карманы» в лавовых потоках. В данном случае, вероятно, это также «газовый карман», но только в подошве грязевого потока. Еще два подобных грота были встречены в обнажениях ДБИ на левом берегу р. Арий около с. Богородское. Возникновение крупного «газового кармана» в подошве грязевого потока возможно лишь при достаточно высокой вязкости последнего.

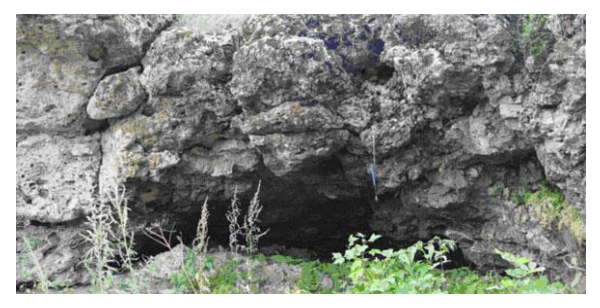

Рис. 14.Крупный «газовый карман» в виде выпуклой вверх линзы в подошве плащеобразного тела ДБИ (лог в борту долины $p$. Арий, северо-западный склон плато)

О высокой вязкости потока ДБИ говорит и наблюдаемая иногда в них «шаровая» отдельность. Правильнее сказать, структуры вращения изометричных блоков с появлением коротких зеркал скольжения. Глядя на такие образования, создается впечатление, что в грязевых потоках, скатывающихся по склону, могли формироваться относительно твердые изометричные блоки, на поверхности которых сохраняются зеркала скольжения. В любом случае в движущемся потоке часть
ДБИ была в твердом состоянии. Об этом свидетельствуют вдавленность отдельных блоков ДБИ в подстилающие мергели, внедрение мергелей и глин в ДБИ и взаимоотношения ДБИ и глинистой части потока.

В вышеописанных обнажениях ДБИ имеют форму пластовых залежей, образованных, вероятно, грязевыми потоками. Совершенно иной характер их залегания наблюдался в траншее на правом берегу р. Арий, в 200-300 м ниже по течению от упомянутого карьера. Долина здесь узкая, с высоким и крутым правым бортом.Долина р. Арий здесь пересекается ЛЭП. Правый борт долины при строительстве ЛЭП был вскрыт глубокой поперечной траншеей. Выработкой вскрыты субгоризонтально залегающие серые доломитистые мергели, местами деформированные и брекчированные. В северовосточной стенке траншеи, на участке со стороны речки, выходят типичные массивные ДБИ. Ширина выхода около 3 м. Контакт с мергелями секущий, неровный, выражен неотчетливо и в целом падает под углом 70-80 восток. Обломочный материал в ДБИ представлен этими же мергелями. К северо-западу от данного тела ДБИ обнажается блок сильно трещиноватого мергеля, шириной около 2,5 м. Затем наблюдается другое тело ДБИ, шириной около 1 м, крутопадающее на юго-восток. Контакты также секущие, неотчетливые и неровные. Далее к западу обнажены только мергели. Залегание мергелей на всех участках траншеи практически одинаковое, субгоризонтальное. Из этого следует, что они не являются ксенолитами, а находятся в первичном залегании. Контакты ДБИ с мергелями секущие, но неровные и неотчетливые. Искривлений плоскостей слоистости мергелей в контакте с ДБИ не наблюдается. Следовательно, говорить о внедрении ДБИ в мергели также не приходится. Не могут быть отнесены данные ДБИ и к «нептуническим дайкам», поскольку границы между ними и мергелями нерезкие. 
Тела ДБИ, вскрытые в северовосточном борту траншеи, прослеживаются и по ее полотну, но морфологию их здесь выяснить не удалось из-за большого количества техногенных отложений. Но на юго-западной стенке траншеи ДБИ отсутствуют, за исключением небольшого извилистого крутопадающего прожилка мощностью от 2 до 20 см (рис. 15). Тело ДБИ прослеживается на всю высоту обнажения (около 3 м высотой). На рис. 15 оно поднимается от рукоятки молотка в верхний левый угол. Хорошо видно развитие каверн и во вмещающем мергеле.
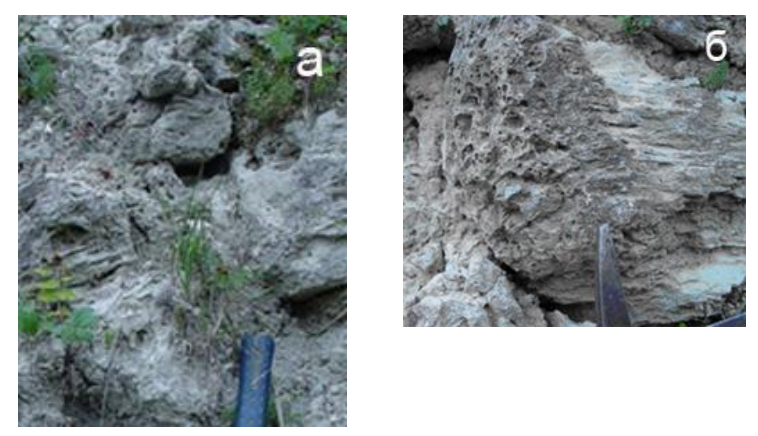

Рис. 15. ДБИ, секущие слоистость мергелей 8 юго-западном борту траншеи на правом борту долины р. Арий (северо-западный склон плато)

Большой уклон слоистости мергеля на рисунке - явление локальное. На рис. 15 , б хорошо видно взаимоотношение между ДБИ и вмещающим мергелем.

\section{Ксеноминералы дырчатых брекчиевых известняков}

Обломочный материал в ДБИ представлен местными породами и «гальками уральского происхождения». Повышенное содержание гравийно-галечного материала наблюдается в ДБИ около д. Верхнее Никитино (рис. 16). Для изучения ксеногенных минералов ДБИ пробы весом от 100 до 300 г пород с различных участков плато растворялись в $10 \%$ растворе соляной кислоты. Нерастворимый остаток разделялся в бромоформе на легкую и тяжелую фракции, которые затем изучались под микроскопом. Изготавливались и изу- чались прозрачные шлифы ДБИ с ксеноминералами.

Установлено, что все ДБИ содержат примесь глинистого материала: от следов до $30 \%$. Содержание ксеноминералов в тяжелой фракции колеблется от ноля до 5,4 г/кг. Минеральный состав их в ДБИ меняется от участка к участку и находится в хорошей согласованности с результатами шлихового опробования данных участков.

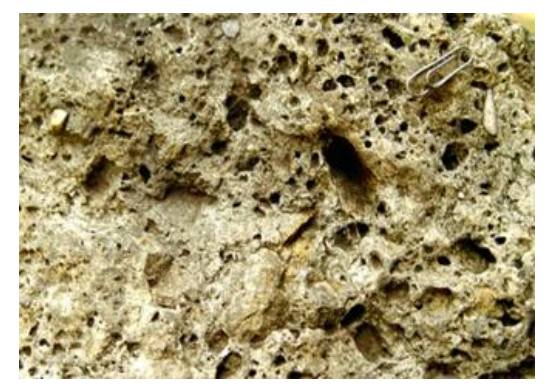

Рис. 16.Мелкие гальки кремнистых пород в ДБИ около д. В. Никитино

Отсюда следует, что источником шлихового материала на плато послужили и ДБИ. Наибольшим распространением пользуются кварц, плагиоклаз, ставролит (доминирует в тяжелой фракции), дистен, силлиманит (в кристаллах и фибролит), мусковит, биотит, циркон, рутил и роговая обманка. Отмечены находки серпентина, хромшпинелидов, пироксенов, магнитных шариков, стекол, шлаковых частиц, муассанита и других минералов. Наибольшее содержание ксеноминералов отмечено в ДБИ около д. В. Никитино, но здесь в тяжелой фракции доминирует эпидот; отмечаются сростки неокатанных кристаллов рубина, в легкой фракции полевые шпаты и кварц без признаков окатанности.

\section{Обсуждение проблемы происхожде- ния ДБИ на Уфимском плато}

1. На Уфимском плато ДБИ встречаются в виде пластовых тел, сходных с затвердевшими грязевыми потоками, и в виде жилоподобных образований, секущих осадочные породы. Типичным оса- 
дочным образованиям отвечают, вероятно, только ДБИ восточной части Предуральского прогиба, тогда как ДБИ Уфимского плато несут признаки трудно совместимые с осадочными образованиями.

2. Каверны в ДБИ имеют либо округлую форму, типичную для газовых пузырей, либо угловатую форму с системой тонких перегородок, типичную для брекчий с селективным растворением. В обоих случаях могут присутствовать обломки известняков и мергелей местного происхождения, но могут и отсутствовать. Встречаются обломки и гравийногалечный материал кремнистых пород и кварца. В одних случаях они могут сильно выступать вовнутрь округлых каверн, в других случаях - ориентированы субпараллельно поверхности крупных каверн. Это показывает, что каверны круглой формы образованы газами и возникли в сильно обводненной брекчии с вязким цементом. Сложнее объяснить образование угловатых каверн, имеющих вид слепков неизвестного твердого и хрупкого вещества. Большинство исследователей ДБИ Уфимского плато считают, что это могли быть гипс, ангидрид или карбонат. Такой вариант решения проблемы вполне возможен, но в таком случае надо объяснить и причину селективного выщелачивания этих минералов, поскольку они входят в состав исследованных ДБИ. Кроме того, гипс - очень мягкий минерал и обломки угловатой формы в составе брекчий должны быть чрезвычайно редки.

3. Шлихоминералогическим картированием установлено наличие на плато комплекса метаморфических минералов, среди которых резко преобладает ставролит. Проблема происхождения ставролита на Уфимском плато обсуждалась в [9]. По типоморфным признакам и ассоциациям установлено зональное распределение минералов на площади плато. Первое появление ставролита, дистена и силлиманита на Уфимском плато отмечается в ДБИ. Данные минералы не могли быть привнесены на плато водными потоками, ветрами или ледниками, поскольку их распределение зональное и ограничено границами структуры - КунгурскоКрасноуфимским сводом, слагающим Уфимское плато.

4. Морфологически минералы шлихов и нерастворимых остатков ДБИ неотличимы друг от друга. Следовательно, либо на момент образования ДБИ данные минеральные ассоциации на плато уже были, либо они появились одновременно.

5. В некоторых ДБИ отмечается минерализованный древесный уголь, что может свидетельствовать об их образовании в условиях суши. Совместное нахождение древесного угля и тяжелых минералов в ДБИ указывает на отсутствие гравитационной сортировки.

6. Наличие в ДБИ и в шлиховом комплексе кроме метаморфических минералов еще и минералов ультраосновногоосновного парагенезиса, стекол и шлаковых частиц, неустойчивого к химическому выветриванию плагиоклаза наводит на мысль о связи ДБИ с эруптивным магматизмом раннепермского времени и позволяет относить их к ксенотуфобрекчиям [7]. Большая мощность осадочного чехла на плато (около 3,0-3,5 км) позволяет предполагать существенно карбонатный состав эруптивных брекчий с переменным содержанием обломков и минералов пород фундамента. Высокая флюидонасыщенность характерна для эруптивных брекчий и хорошо объясняет высокую кавернозность ДБИ.

7. Каверны угловатой формы в ДБИ можно объяснить присутствием газогидратов. Газогидратами называют твердую, замерзшую смесь углеводородов, преимущественно метана и воды. Они относятся к метастабильным минералам, образующимся при определенных температурах и давлениях [11]. До недавнего времени считалось, что газогидраты имеют распространение только в зонах вечной мерзлоты либо на дне холодных океанов и морей. К настоящему времени география их обнаружения значительно расширилась. Они уже найдены не только в высоких широтах, но и ближе к экватору, напри- 
мер, на дне Черного моря и Калифорнийского залива, на Оренбургском своде [10] и других местах. Выясняется, что основные запасы углеводородов на Земле сосредоточены в газогидратах, в связи с чем в некоторых странах, включая США, проводятся специальные исследования по использованию их в качестве энергетического источника [3].

Округлые и угловатые каверны нередко наблюдаются в одном обнажении ДБИ. Иногда каверны заполнены минеральным веществом. Причем характер выполнения каверн обоих типов совершенно аналогичный. Это полости, частично или полностью заполненные глинистым веществом, доломитом (мелкозернистым, сыпучим) или баритом.

Известно, что при адиабатическом прохождении газа через узкое отверстие или пористую среду происходит падение его давления, известное как дросселирование газа, которое сопровождается изменением температуры (эффект Джоуля Томпсона). Количественной характеристикой процесса служит коэффициент Джоуля-Томпсона $\mu$ :

$$
\mu=\Delta T / \Delta P, \text { град/атм, }
$$

где $\Delta \mathrm{T}$ - температурный эффект, а $\Delta \mathrm{P}-$ падение давления. Для реальных газов существует область температур и давлений с $\mu>0$, ограниченная кривой инверсии, за пределами которой $\mu<0$. Охлаждение $(\mu>0)$ газа может быть только при его начальной температуре ниже температуры инверсии. При более высоких начальных температурах процесс сопровождается разогревом газа. Температура инверсии для разных газов различная, например, для воздуха $490^{\circ} \mathrm{C}$, для водорода $-80^{\circ} \mathrm{C}$, для метана $-40^{\circ} \mathrm{C}$.

По мнению некоторых исследователей [1], значительное выделение тепловой энергии на Земле связано именно с расширением газов и отрицательным эфрфектом Джсоля-Томпсона. Ранее автор [7] писал, что образование ДБИ могло быть связано с резкой и массовой дегазацией глубоких горизонтов коры, вызвав- шей разрыхление верхних горизонтов осадочных толщ и потерю ими гравитационной устойчивости (грязевые потоки ДБИ). Одновременно отмечалось, что часть ДБИ скатывалась по склонам к подножью плато, будучи уже в твердом или полутвердом состоянии, и цементировалась такой же водогазонасыщенной карбонатно-глинистой массой.

При $\mu>0$ дросселируемый газ охлаждается и возможно замерзание воды в некоторых объемах грязевого потока, которое создает блоки относительно твердых мёрзлых пород.

8. В связи с вышесказанным образование ДБИ могло проходить следующим образом. В условиях одноосного горизонтального сжатия в раннепермское время формировался Кунгурско-Красноуфимский свод как блок положительного изгиба коры [8]. Прямой градиент стрессовых напряжений, вызванный изгибом, обеспечил отжимание флюидов из ядра блока на верхние горизонты коры. Флюиды относятся к восстановленным, поскольку формировались в условиях высокобарического метаморфизма. Поднявшиеся к апикальной части структуры флюиды явились этой «массовой дегазацией». Выйдя из зоны стрессовых напряжений, газы начинают адиабатически расширяться, разрыхляя породы осадочного чехла и формируя раструбы (диатремы). Наиболее высокие начальные температуры газа будут в крупных каналах, и здесь эффект Джоуля-Томпсона может быть отрицательным, что сопровождается ростом температуры. Этим можно объяснить появление на плато шлаковых частиц, стекол, муассанита, силицидов железа и прочих подобных образований. В мелких каналах начальная температура газов могла быть пониженной ввиду теплообмена с вмещающими породами, что сопровождается положительным эффектом ДжоуляТомпсона с понижением температуры и, возможно, образованием газогидратов. Благодаря эффекту самоконсерващии [11] газогидраты могли сохраняться длительное время, достаточное для консолидации 
породы. На местные локальные напряжения, связанные с уплотнением, просадкой и другими явлениями, они реагировали как хрупкие тела. Со временем, благодаря эрозии, нарушениям условий залегания и прочим изменениям окружающей среды, газогидраты могли претерпеть фазовые переходы и удалиться из породы в виде газов и воды, оставив после себя только каверны угловатой формы. Образованием газогидратов хорошо объясняется не только угловатая форма некоторых каверн, но и повышенная вязкость отдельных блоков ДБИ в грязевых потоках, образование шарообразных блоков, вращающихся в потоке с возникновением «зеркал скольжения», вдавливание блоков ДБИ в подстилающие мергели и пластические внедрения мергелей в «твердые» ДБИ.

Испарение газогидратов должно сопровождаться понижением температуры и выделением свободной воды. Например, фазовыми переходами газогидратов объясняются аномально низкие температуры на забое скважин глубиной около 800 м в районе г. Воркуты и последующее понижение температуры в течение нескольких лет [5]. Возможно, что с этим явлением связано наличие на плато ледяных пещер (Кунгурская ледяная пещера одна из них) и множества родников с холодной водой. Отсутствие признаков таянья льда в устье Енапаевской пещеры (северо-западная граница плато) в конце жаркого лета 2003 г., когда автор посетил пещеру, также можно объяснить генерацией холода при разложении газогидратов. Как отмечено в работе [3], газогидратные воды характеризуются резко опресненным составом. Именно таким составом подземных вод характеризуется площадь Уфимского плато на гидрогеохимической карте [16]. Совмещение на одной площади диатрем эруптивных брекчий и углеводородов явление достаточно обычное. Например, Мирнинское кимберлитовое поле содержит и месторождения нефти [2 и др.].

\section{Заключение}

Собранный фактический материал позволяет предполагать, что ДБИ на Уфимском плато образовались в результате массовой, резкой, интенсивной, неравномерной дегазации глубоких горизонтов земной коры, вызвавшей разрыхление слабо консолидированных осадочных пород, насыщение их водой и газами. Это обусловило гравитационную неустойчивость данных отложений и сползание их в пониженные участки рельефа. Благодаря эффекту дросселирования газа, на одних участках происходил разогрев газов, а на других - их резкое охлаждение с возможным образованием газогидратов и замораживанием грязевых потоков.

На участках наиболее интенсивной дегазации сформировались диатремы эруптивных брекчий, благодаря которым диспергированный материал коры глубоких горизонтов был вынесен на поверхность. Площадной дегазацией и эруптивными брекчиями объясняется: 1) локальность распространения ДБИ на площади плато; 2) большая мощность ДБИ (до 110 м, по В.Д. Наливкину [12]) около восточного подножья плато; 3) появление дайкообразных тел ДБИ; переслаивание ДБИ со слоистыми осадочными образованиями; скопления округлых каверн в мергеле; залегание ДБИ на различных породах; местный обломочный материал в их составе и глубинный ксеногенный материал. Иначе говоря, все наблюдаемое разнообразие ДБИ непротиворечиво объясняется с данных позиций.

Работа выполнена в рамках Проекта УрО РАН № 15-11-5-17.

\section{Библиографический список}

1. Бембель Р.М., Мегеря В.М., Бембель М.Р. Геосолитоны и дегазация Земли // Дегазация Земли: геодинамика, геофлюиды, нефть и газ. М.: ГЕОС, 2002. С. 95-97.

2. Видяпин Ю.П., Лаубенбах Е.А. Пример нетрадиционных нефтекимберлитовых районов углеводородных скоплений // Генезис нефти и газа. М.: ГЕОС, 2003. С. 60-62. 
3. Дмитриевский А.Н., Валяев Б.М. Локализованные потоки глубинных углеводородных флюидов и генезис скоплений газогидратов // Дегазация Земли: геодинамика, геофлюиды, нефть и газ. М.: ГЕОС, 2002. С. 319-322.

4. Дорофеев Н.В. Геологическое строение северной части Уфимского плато (район рр. Шуртана и Сараны) // Тр. ВНИГРИ. Новая серия. 1950. Вып. 44. С. 61-144.

5. Какунов Н.Б. Газогидраты - новый перспективный источник природных газов на территории европейского северо-востока // Геология и минеральные ресурсы европейского северо-востока России. Сыктывкар: Геопринт, 2004. T. IV. C. 124-126.

6. Кисин А.Ю., Коротеев В.А., Сазонов В.Н. Проявление эруптивного магматизма на Уфимском плато // Докл. АН. 2002. Т. 385, № 1. C. $80-82$.

7. Кисин А.Ю. К вопросу о происхождении лемазинских дырчатых брекчиевых известняков на Уфимском плато // Ежегодник-2003 / ИГГ УрО РАН. Екатеринбург, 2004. C. 53-57.

8. Кисин А.Ю. Закономерности размещения и прогноз месторождений полезных ископаемых на основе модели блоковой складчатости // Дис. д-ра геол.-мин. наук. Пермь, 2009. 454 с. (Рукопись).

9. Кисин А.Ю. Минералы ставролитовой ассоциации в платформенном чехле Волго-
Уральской антеклизы: проблема происхождения и возможное решение // Записки PMO. 2010. Ч. 139, вып. 2. С. 92-101.

10. Краюшкин B.A. К природе газогидратов и нефти // Дегазация Земли: геодинамика, геофлюиды, нефть и газ. М.: ГЕОС, 2002. C. $380-382$.

11. Макагон Ю.Ф. Эффект самоконсервации газогидратов // Докл. АН. 2003. Т. 390, № 1. C. $85-89$.

12. Мизенс Г.А. Седиментационные бассейны и геодинамические обстановки в позднем девоне-ранней перми юга Урала / ИГГ УрО РАН. Екатеринбург, 2002. 190 с.

13.Наливкин В.Д. Стратиграфия и тектоника Уфимского плато и Юрезано-Сылвинской депрессии // Тр. ВНИГРИ. Новая серия. 1949. Вып. 46. 206 с.

14. Наливкин В.Д. Фации и геологическая история Уфимского плато и ЮрезаноСылвенской депрессии // Тр. ВНИГРИ. Новая серия. 1950. Вып. 47. $126 \mathrm{c.}$

15. Чувашов Б.И., Дюпина Г.В., Мизенс Г.А., Черных В.B. Опорные разрезы верхнего карбона и нижней перми Западного Урала и Приуралья / УрО АН СССР. Свердловск, $1990.370 \mathrm{c}$.

16. Шестов И.Н. Гидрогеохимическое районирование сероводородных вод Пермской области // Химическая география и гидрогеохимия. Пермь, 1964. Вып. 3 (4). С. 133142.

\section{Foraminated Brecciated Limestone of the Ufimskoe Plateau and its Origin}

\section{A.Yu. Kissin}

Institute of Geology and Geochemistry, Ural Branch of the Russian Academy of Sciences, 15 Academic Vonsovskiy Str., Yekaterinburg 620016, Russia E-mail: kissin@igg.uran.ru

Ufimskoe Plateau is a geomorphological uplift bounding the PreUrals Foredeep in the West at the latitude of the city of Ekaterinburg. At a plateau and the adjacent parts of the through, the unusual foraminated brecciated limestones are widespread. Breccia occurs at the boundary of the Lower and Upper Kungurian Stage and is considered as a sedimentary formation. The results of study led to a conclusion that this limestones formed by a massive outgassing of the underlying parts of a crust, liquefaction of poorly consolidated sedimentary rocks and their sliding to the lower elevation location. Locally the small xenoliths of deep rocks and minerals of eruptive breccia enrich them. It is assumed that drop of pressure took place during passing gas through porous rocks, accompanied by a temperature change (Joule-Thompson effect). This could explain an appearance of glass inclusions, slag particles, and perhaps gas hydrates in the rock. Keywords: Ufimskoe Plateau, deep degassing, eruptive breccia, gas hydrates. 


\section{References}

1. Bembel R.M., Megerya V.M., Bembel M.R. 2002. Geosolitony i degazatsiya Zemli [Geosolitons and degassing oft he Earth]. In Degazatsiya Zemli: geodinamika, geoflyuidy, neft i gaz. Moskva, GEOS, pp. 95-97. (in Russian)

2. Vidyapin Yu.P., Laubenbakh E.A. 2003. Primer netraditsionnykh neftekimberlitovykh rayonov uglevodorodnykh skopleniy [An example of non-traditional oil-kimberlitic regions of hydrocarbon accumulation]. In Genezis nefti i gaza. Moskva, GEOS, pp. 60-62. (in Russian)

3. Dmitrievskiy A.N., Valyaev B.M. 2002. Lokalizovannye potoki glubinnykh uglevodorodnykh flyuidov i genesis skopleniy gazogidratov [Local flows of deep hydrocarbon fluids and genesis of the gas hydrates accumulation]. In Degazatsiya Zemli: geodinamika, geofljuidy, neft' i gaz. Moskva, GEOS, pp. 319322. (in Russian)

4. Dorofeev N.V. 1950. Geologicheskoe stroenie severnoy chasti Ufimskogo plato (rayon rr. Shurtana i Sarany) [Geological structure of the north part of Ufimskoe Plateau (region of Shurtan and Sarany)]. Tr. VNIGRI, Novaya seriya, 44: 61-144. (in Russian)

5. Kakunov N.B. 2004. Gazogidraty - novyy perspektivnyy istochnik prirodnykh gazov na terrtorii evropeyskogo severo-vostoka [Gas hydrates as a new promising source of natural gases at the territory of the European Northeast]. In Geologiya i mineralnye resursy evropeyskogo severo-vostoka Rossii. T.IV, Syktyvkar, Geoprint, pp. 124-126. (in Russian)

6. Kisin A.Ju., Koroteev V.A., Sazonov V.N. 2002. Proyavlenie eruptivnogo magmatizma na Ufimskom plato [Occurrences of eruptive magmatism at the Ufimskoe Plateau]. Dokl. RAN. 385(1): 80-82. (in Russian)

7. Kisin A.Ju. 2004. K voprosu o proiskhozhdenii lemazinskikh dyrchatykh brekchievykh izvestnyakov na Ufimskom plato [About the origin of lemazinian foraminated brecciated limestones at the Ufimsloe Plateau]. In Ezhegodnik-2003. Ekaterinburg, IGG UrO RAN, pp. 53-57. (in Russian)

8. Kisin A.Ju. 2009. Zakonomernosti razmeshcheniya i prognoz mestorozhdeniy poleznykh iskopaemykh na osnove modeli blokovoy skladchatosti [Regularities of distribution and prediction the mineral resources based on the model of the block folding]. Dis. dok. geol.min. nauk. Perm, p. 454. (in Russian)

9. Kisin A.Ju. 2010. Mineraly stavrolitovoy assotsiatsii $\mathrm{v}$ platformennom chekhle VolgoUralskoy antiklizy: problema proiskhozhdeniya i vozmozhnoe reshenie [Minerals of staurolite association in the platform crust of VolgaUrals Anticline: problem of origin and possible solution]. Zapiski RMO, 139(2): 92-101. (in Russian)

10. Krayushkin V.A. 2002. K prirode gazogidratov i nefti [About nature of gas hydrates and oil]. In Degazatsiya Zemli: geodinamika, geoflyuidy, neft i gaz. Moskva, GEOS, pp. 380-382. (in Russian)

11. Makagon Yu.F. 2003. Effekt samokonservatsii gazogidratov [Effect of selfpreservation of gas hydrates]. Dokl. RAN. 390(1): 85-89. (in Russian)

12. Mizens G.A. 2002. Sedimentatsionnye bassejny i geodinamichskie obstanovki $\mathrm{v}$ pozdnem devone - ranney permi yuga Urala [Sedimentation basins and geodynamic environments in the Late Devonian and Early Permian of South Urals]. Ekaterinburg: IGG UrO RAN, p. 190. (in Russian)

13. Nalivkin V.D. 1949. Stratigrafiya i tektonika Ufimskogo plato i Yurezano-Sylvinskoy depressii [Stratigraphy and tectonics of Ufimskoe Plateau and Yurezano-Sylvinskaya Depression]. Tr. VNIGRI, Novaya seriya, V.46, p. 206. (in Russian)

14. Nalivkin V.D. 1950. Fatsii i geologicheskaya istoriya Ufimskogo plato i JurezanoSylvinskoy depressii [Facies and geological history of Ufimskoe Plateau and YurizanoSylvinskaya Depression]. Tr. VNIGRI, Novaya seriya, V.47, p. 126. (in Russian)

15. Chuvashov B.I., Dyupina G.V., Mizens G.A., Chernykh V.V. 1990. Opornye razrezy verkhnego karbona i nizhnej permi zapadnogo Urala i Priuralya [Reference sections of Upper Carboniferous and Lower Permian of the west Urals and PreUrals]. Sverdlovsk, UrO AN SSSR, p. 370. (in Russian)

16. Shestov I.N. 1964. Gidrogeokhimicheskoye rayonirovanie serovodorodnykh vod Permskoy oblasti [Hydrochemical zonation of hydrosulfuric waters of Perm region]. Khimicheskaya geografiya i gidrogeokhimiya. 3 (4): 133-142. (in Russian) 